UDC: $630 * 561.24$

\author{
I. M. KOVAL ${ }^{1,3}$, assist. prof., PhD, A. BRÄUNING ${ }^{2}$, prof., Dr., E. E. MELNIK ${ }^{3}$, \\ V. O. VORONIN ${ }^{1}$ \\ ${ }^{1}$ V. N. Karazin Kharkiv National University, \\ Svobody Sq. 6, 61077, Ukraine, \\ Koval_Iryna@ukr.net \\ ${ }^{2}$ Institute of Geography, Friedrich-Alexander-Universität Erlangen-Nürnberg \\ Wetterkreuz 15, 91058 Erlangen, Germany \\ ${ }^{3}$ Ukrainian Research Institute of Forestry and Forest Melioration named after G. M. Vysotsky \\ Pushkinska st. 86, Kharkiv, 61024, Ukraine
}

\title{
DENDROCLIMOTOLOGICAL RESEARCH OF SCOTS PINE IN STAND OF THE LEFT-BANK FOREST-STEPPE OF UKRAINE
}

\begin{abstract}
Purpose of this research was to detect influence of climatic change on pine radial increment in stand in the Left-bank Forest-steppe of Ukraine as example 100-years-old stand at State Enterprise 'Kharkiv forest scientific research station'. Methods. Dendrochronological. Method of correlation function and multiple regressions (response function) were used to analyze the influence of climatic factors on tree radial increment. For this purpose computer program RESPO was used. Results. Tree ring series were built and were used for correlation analysis between climatic factors and pine radial increment for two periods: 1960-1988 and 1988-2016. Years of minimum $(1933,1942,1956,1972,1976,1976,1987,1992,2002,2006$ та 2012) and maximum $(1933,1942,1956$, 1972, 1975, 1976, 1979, 1979, 1979, 1987, 1992, 2002 та 2012) of radial increment were detected. Depressions of pine radial increment were as a result of negative weather conditions: low and high winter and early-spring temperature, droughts during vegetation period. Maximums of radial increments were depended on favorable weather conditions for pine radial growth. Correlation and Response analysis for two periods showed that increase of temperature and precipitation, excluding winter precipitation, changed response of forest ecosystems to climatic change: if in first period (1960-1988) radial increment limited by April temperature and together July temperature positively influenced on radial growth, in second period (1988-2016) June temperature negatively infuenced on radial increment. Slight increase precipitation during vegetation period could not soften impact if high temperature during vegetatation period on tree radial increment. Conclusions. At comparison 1960-1988 and 1988-2016 it was detected that during first period positive influence of summer temperature on radial growth was distinctive and for second period one started to limit increment (negative influence) were detected. Slight increase of precipitation for vegetation period in second period significantly didn't influence on pine radial growth. In second period increase of winter temperature and number of thaws negatively influenced on soil moisture, decreased of tree ring widths.
\end{abstract}

Key words: radial increment, pine, climatic change

Коваль І. М. ${ }^{1,3}$, Браунінг А. ${ }^{2}$, Мельник С. С. ${ }^{3}$, Воронин В. О. ${ }^{1}$

${ }^{1}$ Харківський національний університет імені В. Н. Каразіна

${ }^{2}$ Iнститут географіі, університет Фрідріха_Александра міст Ерлангена та Нюрнберга

${ }^{3}$ Український науково-дослідний інститут ліссового господарства та агролісомеліорації імені Г. М. Висоиького

ДЕНДРОКЛІМАТОЛОГІЧНІ ДОСЛІДЖЕННЯ СОСНИ ЗВИЧАЙНОЇ В НАСАДЖЕННІ ЛІВОБЕРЕЖНОГО ЛІСОСТЕПУ УКРАЇНИ

Мета. Виявлення впливу змін клімату на радіальний приріст сосни в Лівобережному степу на прикладі 100-річного соснового насадження ДП «Харківська лісова науково-дослідна станція». Методи. Дендрохронологічні. Результати. Створено деревно-кільцеві хронології, які використано у встановленні зв'язків між кліматичними чинниками та радіальним приростом сосни за два періоди: 1960-1988 та 19882016 рр. Кореляційний аналіз та функція відгуку за два періоди показали, що при збільшенні температур та кількості опадів (виняток - зимові опади) змінилася реакція лісових екосистем на зміни клімату: так, якщо в першому періоді (1960-1988 рр.) радіальний приріст обмежували квітневі температури, водночас позитивно впливали липневі температури, то у другому періоді (1988-2016 рр.) червневі температури вже негативно впливали на приріст. Незначне збільшення кількості опадів за вегетаційний період не змогли пом'якшити вплив високих температур вегетаційного періоду на радіальний приріст. Висновки. При порівнянні 1960-1988 та 1988-2016 рр. виявлено, що якщо для першого періоду характерний позитивний вплив літніх температур на радіальний приріст, то для другого періоду вони починають обмежувати приріст. Незначне збільшення кількості опадів за вегетаційний період у другому періоді не змогло пом’якшити вплив високих температур на радіальний приріст дерев.

Ключові слова: радіальний приріст, сосна звичайна, зміни клімату

(C) Koval I., Bräuning A., Melnik E., Voronin V. O., 2017

DOI: https://doi.org/10.26565/1992-4224-2017-28-07 


\begin{abstract}
Коваль И. М. ${ }^{1,3}$, Браунинг А. ${ }^{2}$, Мельник Е. Е. ${ }^{3}$, Воронин В. О. ${ }^{1}$
${ }^{1}$ Харьковский национальный университет имени В. Н. Каразина

${ }^{2}$ Институт географии при Университете им. Фридриха-Александра городов Эрлангена и Нюрнберга

${ }^{3}$ Украинский научно-исследовательский институт лесного хозяйства и агролесомелиораџии имени Г. Выссоикого

\section{ДЕНДРОКЛИМАТИЧЕСКИЕ ИССЛЕДОВАНИЯ СОСНЫ ОБЫКНОВЕННОЙ В НАСАЖ- ДЕНИИ ЛЕВОБЕРЕЖНОЙ ЛЕСОСТЕПИ УКРАИНЫ}

Цель. Выявление влияния изменений климата на радиальный прирост сосны в Левобережной степи Украины на примере 100-летнего соснового насаждения ГП «Харьковская лесная научноисследовательская станция». Методы. Дендрохронологические. Результаты. Созданы древеснокольцевые хронологии для установления связей между климатическими показателями и радиальным приростом сосны за два периода: 1960-1988 та 1988-2016 гг. Корреляционный анализ и функция отклика за два периода показали, что при увеличении температур и количества осадков (исключением стали зимние осадки) изменилась реакция лесных екосистем на вариации условий природной среды. Так, если в первом периоде (1960-1988 гг.) радиальный прирост ограничивали апрельские температуры, в то же время на прирост положительно влияли летние (июльские) температуры, то во втором периоде летние температуры (июнькие) стали негативно влиять на прирост деревьев. Незначительное увеличение количества осадков за вегетационный период не смогло смягчить влияние высоких температур вегетационного периода на радиальный прирост. Выводы. При сравнении 1960-1988 и 1988-2016 гг. выявлено, что для первого периода характерно положительное влияние летних температур на радиальный прирост, однако для второго периода они начинают ограничивать прирост деревьев. Незначительное увеличение количества осадков за вегетационный период не смогло смягчить влияние высоких температур вегетационного периода на радиальный прирост.
\end{abstract}

Ключевые слова: радиальный прирост, сосна обыкновенная, изменения климата

\title{
Introduction
}

For the past 100 years temperature increases by $0.4-0.6^{\circ} \mathrm{C}$ in Ukraine [1].This climatic change will be able to move natural habitats and borders of forest areas, changes of dominant tree species and level of resistance of forest ecosystems [3]. As result of growing of stands in relatively favourable climatic and soil conditions, to reveal complex of factors limited tree growth sometimes enough difficult because it changes during calendar year.

In previous studies it was elicited tree ring formation in stands growing in conditions of temperate climate are limited by temperatures of the growing period, early spring and winter, as well precipitation for the growing period $[4,5,6,8,9]$.

\section{Materials and methods}

Dendrochronological methods were used $[2,10,11,12]$. Pine cores were collected in 100 years old pine stand growing at the State Enterprise 'Kharkiv forest scientific research station' (quarter №159, board №2, latitude $50^{\circ} 03^{\prime} 27^{\prime \prime} \mathrm{N}$, longitude $\left.36^{\circ} 21^{\prime} 08^{\prime \prime} \mathrm{E}\right)$. Main taxation indices of planting: average height of trees is $24 \mathrm{~m}$, average diameter trees is $42 \mathrm{sm}$, estimated productivity II, type of forest $\mathrm{B}_{2}-\mathrm{dC}$ (fresh pine-oak subor), degree of density 0.6, tree volume for 1 ha $/ 310 \mathrm{~m}^{3}$.

Cores were taken by Pressler borer at $1.3 \mathrm{~m}$ of trunk of dominant and undamaged
The current increase of average temperature caused to necessity of adaptation of forest ecosystems to new conditions. Study of change of response of forest ecosystems to change of climate is very important. By reason of tree rings record not only information about changes in natural environment, also the tree response to these changes. So tree rings will able to be as biological indicators and integral factor of state of forest ecosystems.

Aim of this study was elicitation of influence of climate change on pine radial growth in stands of the Left-bank Forest-steppe in Ukraine on example 100 year old pine stand in South forestry. 
Indexing of tree-ring chronologies was realized using the program ARSTAN to move away age trend. This makes it possible to analyze response of pine radial growth to climatic factors using the program RESP from the program set DPL [10]. We used index tree ring STANDART to analyze influence of climate on pine radial growth because the best results were gotten with this tree ring index chronology.

Correlation analysis and multiple regressions were used for revelation of influence of climate on radial growth by the program RESPO. Values of STANDART chronology were used as independent variables while the aver- age monthly air temperature values and the average monthly precipitation values for 19592016 for the period from June to September of the current year, have been applied as variables. The data of the Kharkiv meteorological station at the airport $\left(49^{\circ} 55^{\prime} \mathrm{N}, 36^{\circ} 17^{\prime} \mathrm{E}, 152\right.$ $m$ altitude) for the period 1959-2016 was used. The average monthly temperature and monthly precipitation values for the Kharkiv meteorological station are presented on fig. 1. The most warm $\left(21.9{ }^{\circ} \mathrm{C}\right)$ and humid $(70 \mathrm{~mm})$ month was July, and the coldest month - January $\left(-4.6^{\circ} \mathrm{C}\right)$. The minimum precipitation was noted in March.

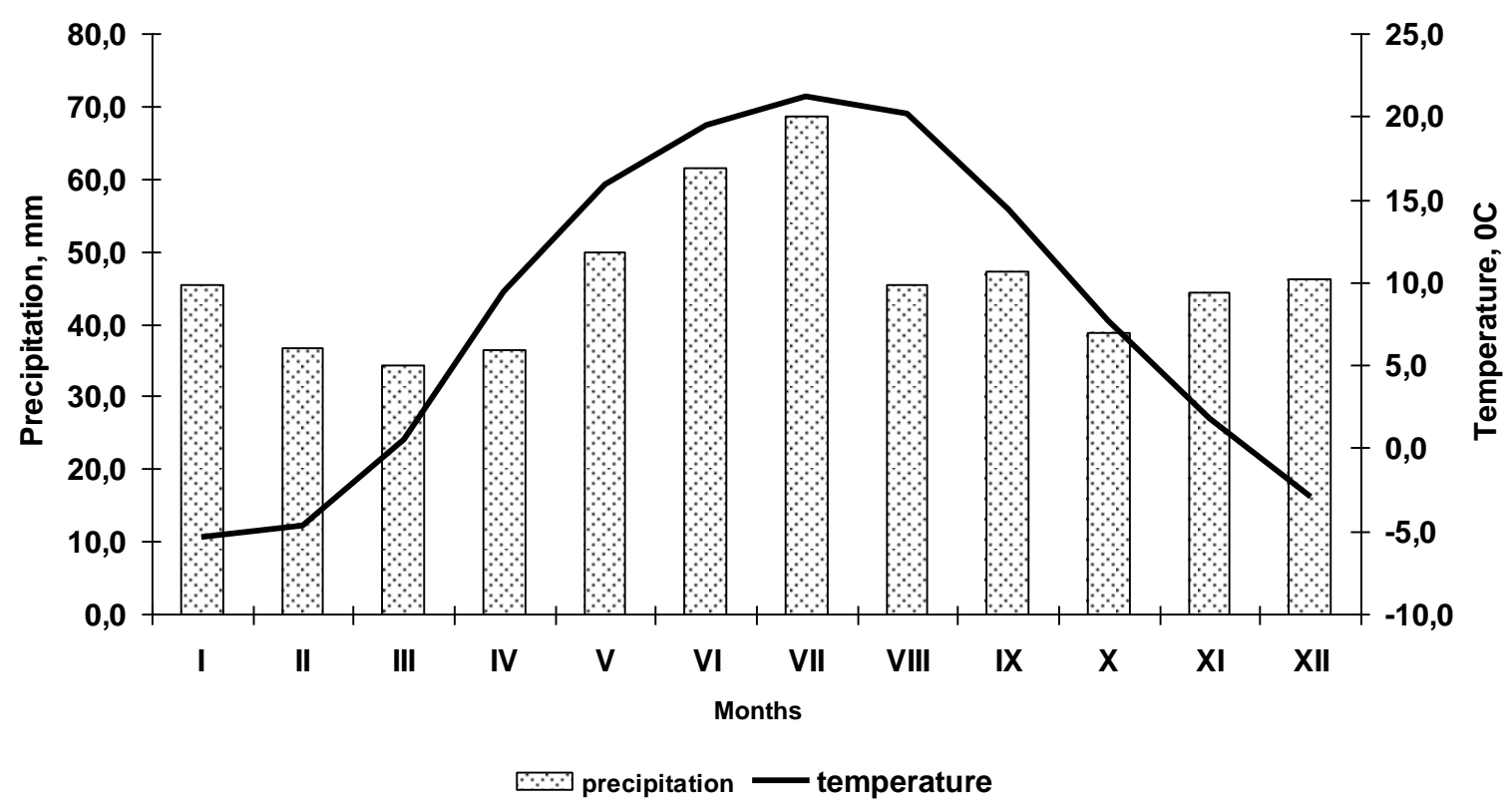

Fig. 1 - Climatogram of Kharkiv Meteorological Station

\section{Results and discussion}

The dynamics of the pine radial growth for all types of wood is presented in Fig. 1. The years of minimum and maximum growth, which are called the pointer years, in which about $90 \%$ of trees have the same growth trend are revealed. Years of minimal growth: 1933, 1942, 1956, 1972, 1976, 1976, 1987, 1992, 2002, 2006, and 2012; years of maximum growth: 1933, 1942, 1956, 1972, 1975, 1976, 1979, 1979, 1979, 1987, 1992, 2002, and 2012 (Fig. 2).

Depression of the pine radial growth was due to negative weather conditions (low and high winter and early spring temperature; droughts during the growing season). Maximum radial growth was as result favorable weather conditions (Fig. 2, 3, 4).

Climatic indicators during two periods (1960-1988 and 1988-2016) were compared. In the last years of 1988-2016, compared with 1960-1988, the average annual temperature increased by $1.2^{\circ} \mathrm{C}$, during the growing season - by $0.9^{\circ} \mathrm{C}$, during the winter - by $1.7^{\circ} \mathrm{C}$ and in March - at $2.1^{\circ} \mathrm{C}$. Low increase in precipitation for growing period (by $19 \mathrm{~mm}$ ), and at the same time, the winter precipitation decreased by $15 \mathrm{~mm}$ were noted (Table 1). The biggest changes occurred for winter and early autumn temperatures.

For 2009-2016 a significant increase in temperatures during the growing season was noted, which negatively affected the radial increment (Fig. 1, 2.). Deviation from the norm of this temperature was $9 \%\left(1.7^{\circ} \mathrm{C}\right)$, while the indices of radial growth decreased by $4 \%$ during this period. 


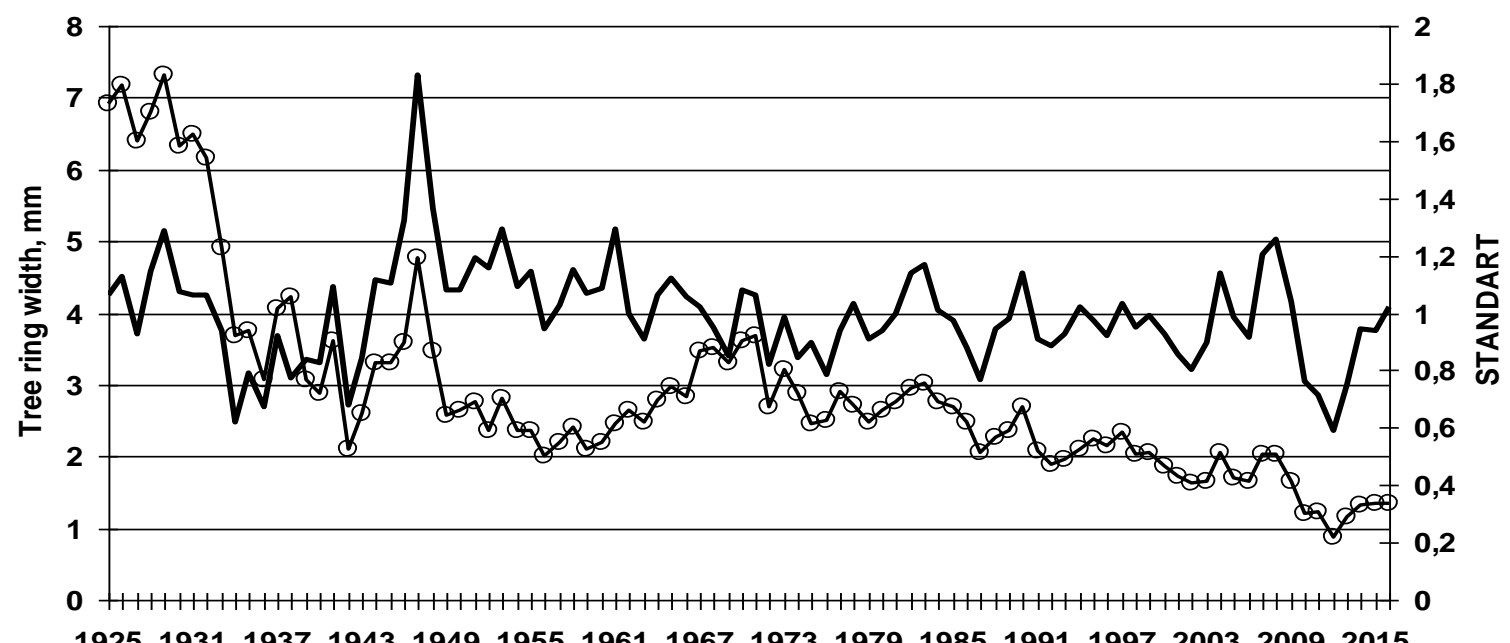

1925193119371943194919551961196719731979198519911997200320092015

Years

$\checkmark$ - Tree ring width - STANDART chronology

Fig. 2 - Dynamics of the tree ring chronology and the index tree ring STANDART chronology

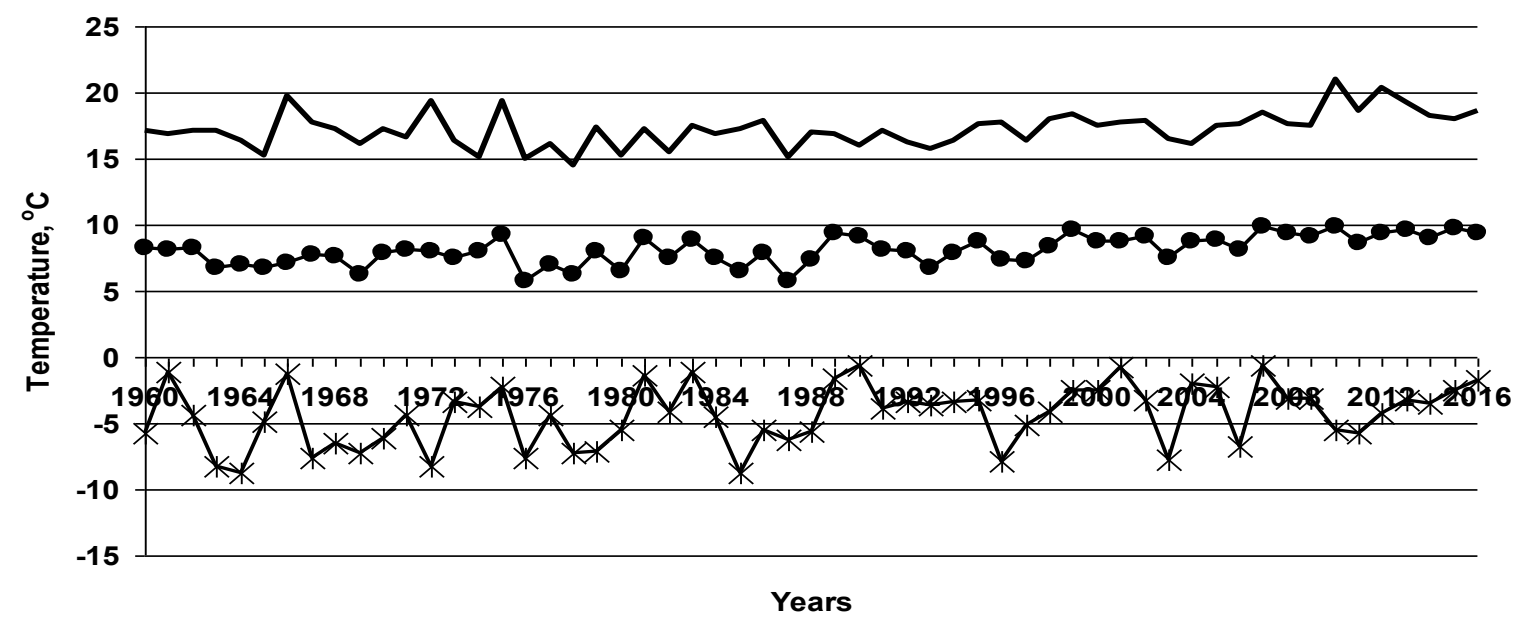

Mean temperature for: $\rightarrow$ year - IV-VIII months $\rightarrow$ winter months

Fig. 3 - Dynamics of temperature (data of the Kharkiv meteorological station)

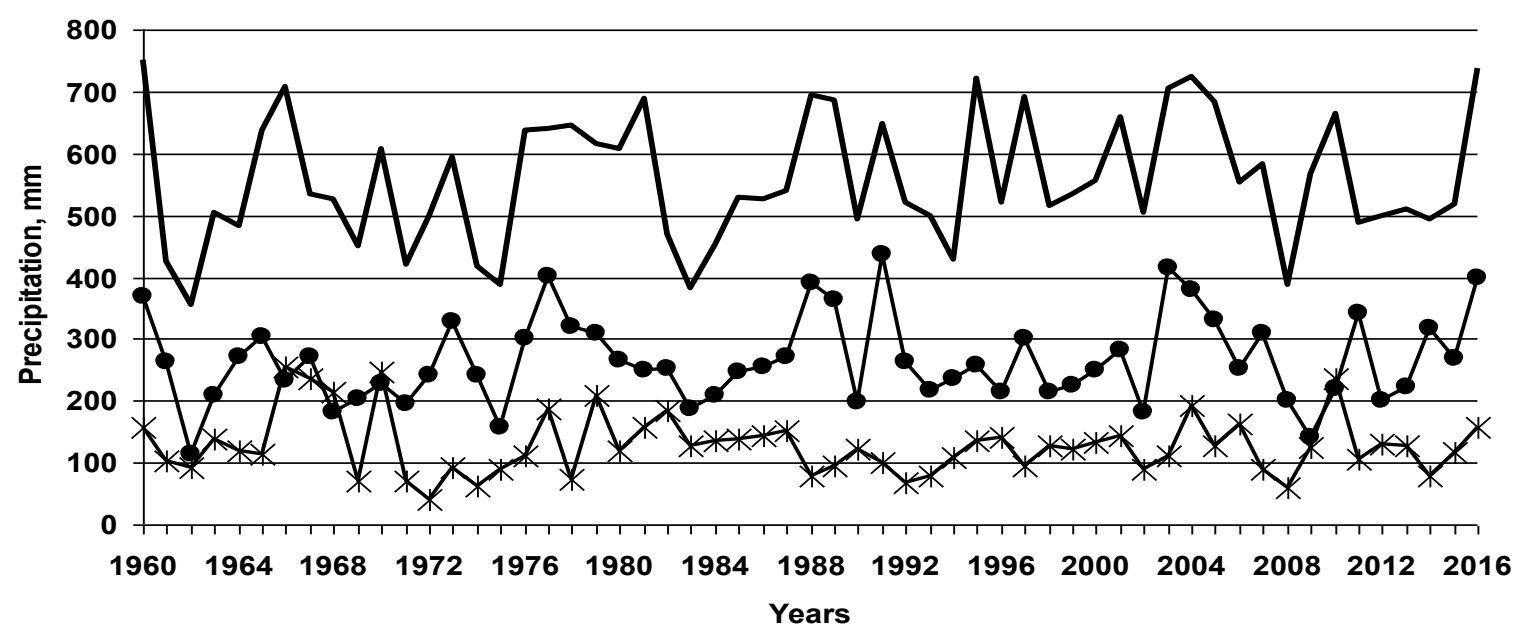

Середня сума опадів за: - рік - IV-VIII місяці $\rightarrow$ ж зиму

Fig. 4 - Dynamics of precipitation (data of the Kharkiv meteorological station) 
Difference between climatic factors and STANDART index chronology for two periods: 1960-1988 and 1988-2016

\begin{tabular}{|c|c|c|c|}
\hline & \multicolumn{2}{|c|}{ Periods, years } & \multirow{2}{*}{$\begin{array}{l}\text { Difference in \% between first } \\
\text { and second periods }\end{array}$} \\
\hline & 1960-1988 & 1988-2016 & \\
\hline \multicolumn{4}{|c|}{ Average temperature $\left({ }^{\circ} \mathrm{C}\right)$} \\
\hline Year & 7,5 & 8,7 & 14 \\
\hline IV-VIII months & 16,8 & 17,7 & 5 \\
\hline winter & $-5,3$ & $-3,6$ & 32 \\
\hline III month & $-0,67$ & 1,8 & 63 \\
\hline \multicolumn{4}{|c|}{ Precipitation (mm) } \\
\hline year & 542 & 579 & 7 \\
\hline IV-VIII months & 258 & 277 & 7 \\
\hline winter & 134 & 119 & -11 \\
\hline \multicolumn{4}{|c|}{ Index tree ring chronology STANDART } \\
\hline & 0,98 & 0,95 & -4 \\
\hline
\end{tabular}

The correlation coefficient $(0.44)$ between tree ring chronologies for all trees allows realization of correlation analysis between radial growth and climatic factors (Table 2).

The coefficient of autocorrelation of the first order, which characterizes how closely tree ring width of the annual ring of this year is related to the tree ring width of the previous year[11], was high (Table 2). This indicates the favorable forest and climatic conditions for growing pine stands.

Table 2

Statistics of tree-ring chronology of pine annual tree ring width and pine index tree-ring chronology

\begin{tabular}{|c|c|c|c|c|c|c|c|}
\hline & $\begin{array}{c}\text { Inter- } \\
\text { val, } \\
\text { years }\end{array}$ & $\begin{array}{c}\text { Average, } \\
\text { mm / } \\
\text { relative } \\
\text { units }\end{array}$ & $\begin{array}{c}\text { Average } \\
\text { sensitivity }\end{array}$ & $\begin{array}{c}\text { Standard } \\
\text { deviation }\end{array}$ & $\begin{array}{c}\text { Autocorrelation } \\
\text { 1st order }\end{array}$ & $\begin{array}{c}\text { Number } \\
\text { tree rings, } \\
\text { pieces }\end{array}$ & $\begin{array}{c}\text { Internal } \\
\text { correlation } \\
\text { coefficient }\end{array}$ \\
\hline $\begin{array}{c}\text { Radial } \\
\text { growth }\end{array}$ & $\begin{array}{c}1925- \\
2016\end{array}$ & 2,63 & 0,21 & 1,62 & 0,88 & 810 & 0,44 \\
\hline$S^{*}$ & $\begin{array}{c}1925- \\
2016\end{array}$ & 1,00 & 0,133 & 0,179 & 0,57 & 809 & \\
\hline
\end{tabular}

\footnotetext{
*-STANDART index-tree chronology
}

The correlation analysis and the response function for two periods showed that with the increase of temperatures and precipitation (the exception is winter precipitation), the reaction of forest ecosystems to the influence of climate changes, as in 1960-1988, the radial growth was limited the low April and high July temperatures, then later, in 1988-2016 negatively affected the radial increase of September tem- peratures of the previous year which are influence on winter wet accumulation, and the negative influence of June temperatures. There was a slight increase in precipitation, but on the background of high temperatures negative correlations between the indices of radial growth and precipitation became more in the second period than in the first one (Fig. 5). 


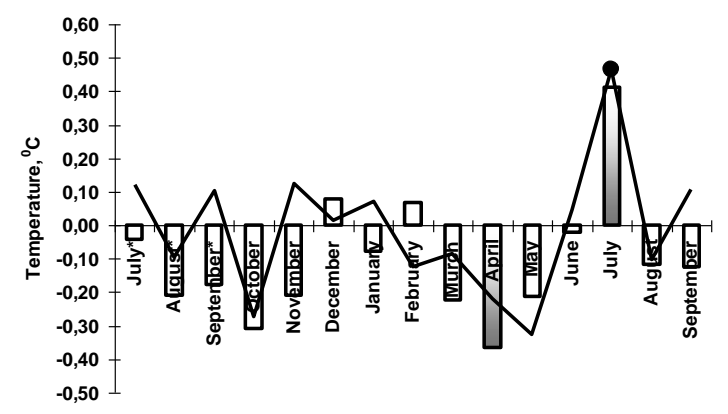

$\square$ Correlation - Response

a) Temperatures for the first period of 1960-1988

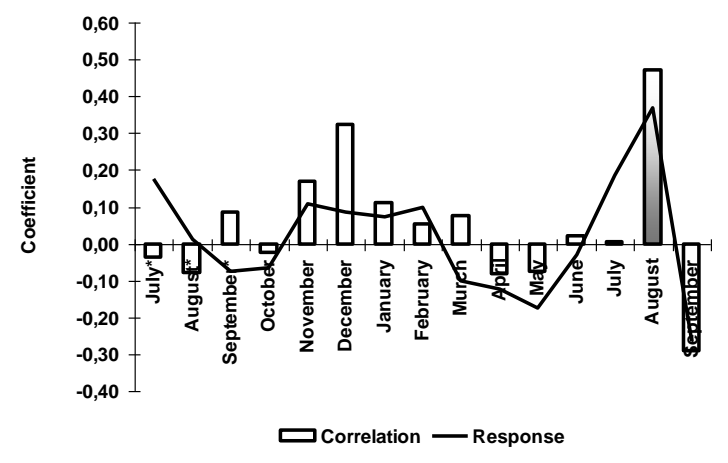

c) Precipitation for the first period of 1960-1988

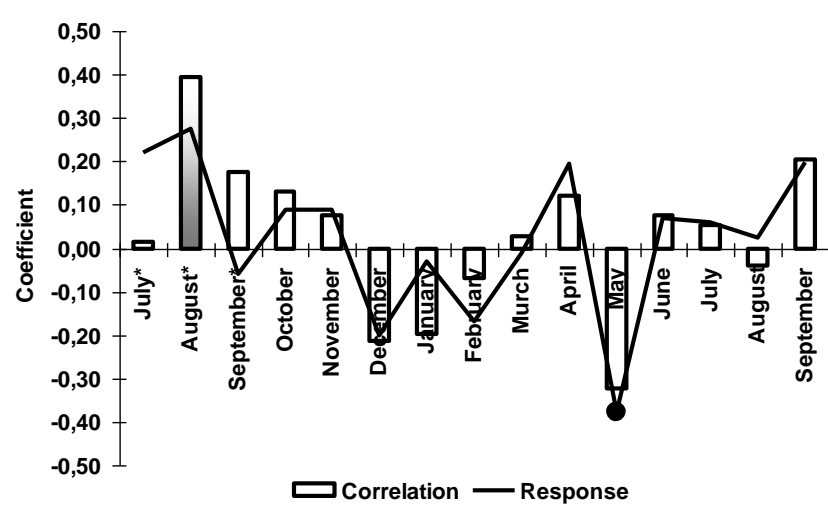

b) Temperatures for the second period of 1988-2016

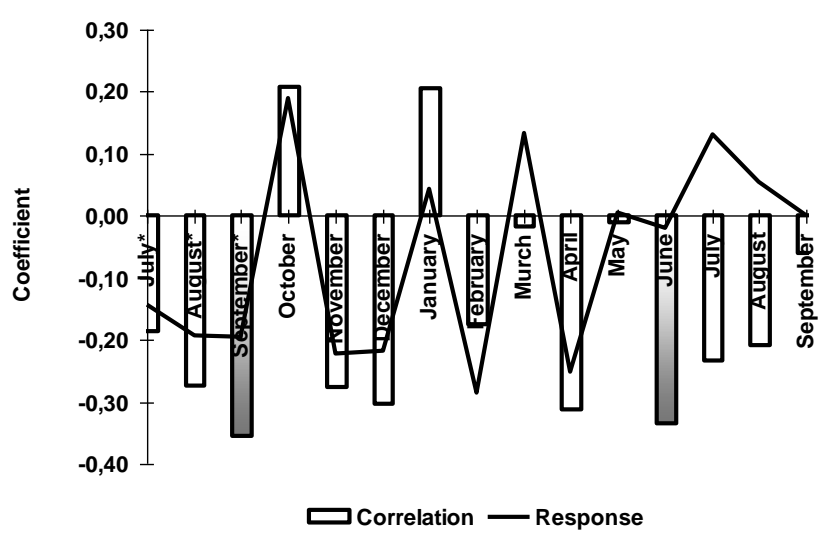

d) Precipitation for the second period 1988-2016

Fig. 5 - Correlation analysis and analysis of the response function for the average monthly temperatures and the STANDART index chronology for annual tree ring widths. Significant correlations at 0.05 level are indicated by gray columns, and significant correlations between temperatures and radial growth are marked by black circles

In the first period of 1960-1988, there was a positive effect of precipitation on radial growth in the 1960-1988 because on the background of low winter temperatures there was moisture accumulation in the soil, but in the next years 1988-2016 this influence became opposite - negative, which is probably due to an increase in winter and early spring temperatures, which did not contribute to the formation of a constant snow cover. As a result of thawing during the winter there was no moisture accumulation at the level of the past 19601988., which negatively affected the formation of tree ring widths.

D.V. Tishin [7] also showed an increase in the negative effects of winter precipitation on radial growth, due to the increase in winter temperatures and flooding over the past years. Such a reaction of radial growth to the influence of winter precipitation can be due not only to climate fluctuations, but also to changes in groundwater levels.

\section{Conclusions}

At comparison 1960-1988 and 19882016, it was revealed that for the first period, the positive influence of summer temperatures on the radial growth is characteristic, while for the second period they begin to limit the radial growth. A slight increase in precipitation for growing period could not mitigate the negative influence of high temperatures on the formation of tree rings. In the second period, the increase of the negative influence of winter precipitation on growth, which was caused by an increase in winter temperatures and thaw, was found to have a negative effect on the wet accumulation of soil and the formation of annual pine rings.

Acknowledgements. The authors are most grateful to Iris Burchardt from Dendrochronological laboratory at Institute of 
Geography at Friedrich-Alexander-Universität Erlangen-Nürnberg, who helped a lot with

measurement and dating tree rings.

\section{Лimepamypa}

1. Дідух Я. Екологічні аспекти глобальних змін клімату. Причини, наслідки, дії. Вісн. НАН України. 2009, № 2. C. 34-44.

2. Битвинскас Т.Т. Дендроклиматические исследования. Л.: Гидрометеоиздат. 1974. 170 с.

3. Букша І. Ф., Гожик П. Ф., Смельянова Ж. Л., Трофимова І. В., Шершевський А. І.; ред.: В. В. Васильченко, М. В. Рапцун. Україна та глобальний парниковий ефект. Ч. 2. Вразливість і адаптація екологічних та економічних систем до зміни клімату. К. : Агентство з раціон. використ. енергії та екол., 1997. $206 \mathrm{c}$.

4. Коваль І.М. Вплив клімату та забруднення на динаміку радіального приросту сосни звичайної в лісостеповій зоні. Вісник Харківського Начіонального Аграрного Університету імені В.В. Докучаєва. Серія «Ірунтознавство, агрохімія, землеробство, лісове господарство. 2013. Вип. 1. С. 209-212.

5. Коваль І.М., Бологов О.В., Нусбаум С.А., Юзвинський Г.А. Радіальний приріст дуба звичайного та ясена звичайного як індикатор стану лісових екосистем в умовах Новоград-Волинського фізикогеографічного району. Лісівнищтво і агролісомеліораиія : зб. наук. праць. Харків: Вид-во УкрНДІЛГА. 2015. Вип. 126. С. 202-211.

6. Коваль І.М., Токарева Н.А., Невмивка М.В., Воронін В.О. Динаміка радіального приросту дерев, пошкоджених пожежею, в соснових насадженнях Лісостепової зони Харківщини. Вісник Харківського національного університету імені В.Н. Каразіна Серія "Екологія", вип.15, 2016. С. 81-88.

7. Тишин Д.В., Чижикова Н.А., Чугунов Р.Г.Радиальный прирост сосны (Pinus Sylvestris L.) верхових болот как индикатор локальных изменений климата. Лесной вестник. №5. 2014. 177-182.

8. Bräuning Achim, Maaike De Ridder, Nikolay Zafirov, Ignacio García-González; Dimitar Petrov Dimitrov and Holger Gärtner Tree-ring features: sndicators of extreme event impacts. IAWA Journal. 2016. Vol. 37 (2), 206.

9. Grissino Mayer Henri D. Evaluating accuracy: a manual and tutorial for the computer program COFECHA. Tree-ring research. 2001. Vol. 57(2), 205-221.

10. Holmes, R.J. Dendrochronology Program Library-Users Manual; University of Arizona: Tucson, AZ, USA. 1994, 51.

11. Holmes, R.L., Adams R.K, Fritts H.C. Tree ring chronologies of western North America: California, eastern Oregon and northern Great Basin, with procedures used in the chronology development work, including users manuals for computer programs COFECHA and ARSTAN. Chronology Series VI Laboratory of TreeRing Research . Tucson : University of Arizona. 1986

12. Methods of Dendrochronology. Applications in the Environmental Sciences. Edward R. Cook and Leonardas A. Kairiukstis (editors). Doredrecht, the Netherlands: Kluwer Academic Publishers and International Institute for Applied Systems Analysis, 1990. 394.

13. Koval Iryna. Climatic signal in earlywood, latewood and total ring width of Crimean pine (Pinus nighra subsp. Pallasiana) from Crimean Mountains, Ukraine. Baltic Forestry. 2013.Vol. 19(2), 245-251.

14. Maxime, C. \& Hendrik, D. Effects of climate on diameter growth of cooccurring Fagus sylvatica and Abies alba along an altitudinal gradient . Trees. 2011. 25:2, 265-276.

15. Orwig, D.A. \& Abrams, M.D. 'Variation in radial growth responses to drought among species, site, and canopy strata. Trees. 1997. 11:8, 474-484.

16. Pilcher, J.R. \& Gray, B. The relationships between oak tree growth and climate in Britain. Journal of Ecology.1982. 70:1, 297-304.

\section{References}

1. Didukh. Ya. (2009) Ekolohichni aspekty hlobal'nykh zmin klimatu. Prychyny, naslidky, diyi [Ecological aspects of global of climativ changes]// Herald of the NAS of Ukraine. 2, 34-44 [In Ukrainian].

2. Bitvinskas T.T. (1974). Dendroklimaticheskie issledovaniya [Dendroclimatogical research]. L.: Gidrometeoizdat. 170 p. [In Russian].

3. Buksha I. F., Hozhyk P. F., Yemel'yanova Zh. L., Trofymova I. V., Shershevskyy A. I. (1997). Ukrayina ta hlobalnyy parnykovyy efekt [Ukraine and Global greenhouse effect]. Ch. 2. Vrazlyvist' i adaptatsiya ekolohichnykh ta ekonomichnykh system do zminy klimatu [Sensitivity and adapation of ecological and economic systems to climatic changes]. K. : Ahent·stvo z ratsion. vykoryst. enerhiyi ta ekol. 206 p. [In Ukrainian].

4. Koval I.M. (2013). Vplyv klimatu ta zabrudnennya na dynamiku radial'noho pryrostu sosny zvychaynoyi v lisostepoviy zoni [Influence of climate and pollution on dynamics of radial growth of Scots pinein Forest Steppe zone . Bulletin of Kharviv National Agrarian University after V.V. Dokuchayev. 1, 209-212 [In Ukrainian]. 
5. Koval I.M., Bolohov O.V., Nusbaum S.A., Yuzvynskyy H.A. (2015). Radialnyy pryrist duba zvychaynoho ta yasena zvychaynoho yak indykator stanu lisovykh ekosystem v umovakh Novohrad-Volyns'koho fizykoheohrafichnoho rayonu [Radial increment of oak and ash trees as indicator of forest ecosystems condition in Novograd-Volynsky physiographic region // Forestry and Forest Melioration: Kharkiv: UkrNDILHA. 2015. №. 126б 202-211 [In Ukrainian].

6. Koval I.M., Tokareva N.A., Nevmyvka M.V., Voronin V.O. (2016). Dynamika radialnoho pryrostu derev, poshkodzhenykh pozhezheyu, v sosnovykh nasadzhennyakh Lisostepovoyi zony Kharkivshchyny [Dynamic of radial growth trees damaged by fire in pine stands in forest-steppe zone of Khariv region.] . Visnyk of V.N. Karazin Kharkiv National University . Series Ecology .15, 81-88. [In Ukrainian].

7. Tyshyn D.V., Chyzhykova N.A., Chuhunov R.H. (2014). Radialnyy pryrost sosny (Pinus Sylvestris L.) verkhovykh bolot kak yndykator lokal'nykh yzmenenyy klymata [High-moor bogrine (Pine (pinus Sysvestris L.. Radial growth as indivcator of local climate changes // Forestry Bulletin. № 5, 177-182. [In Russian].

8. Bräuning Achim, Maaike De Ridder, Nikolay Zafirov, Ignacio García-González; Dimitar Petrov Dimitrov and Holger Gärtner (2016) Tree-ring features: sndicators of extreme event impacts . IAWA Journal. 37 (2), 206.

9. Grissino Mayer Henri D. (2001) Evaluating accuracy: a manual and tutorial for the computer program COFECHA . Tree-ring researchVol. 57(2), 205-221. [in English].

10. Holmes, R.J. (1994) Dendrochronology Program Library-Users Manual; University of Arizona: Tucson, AZ, USA. 1994, 51. [in English].

11. Holmes, R.L., R.K Adams, H.C. Fritts (1986) Tree ring chronologies of western North America: California, eastern Oregon and northern Great Basin, with procedures used in the chronology development work, including users manuals for computer programs COFECHA and ARSTAN. Chronology Series VI Laboratory of Tree-Ring Research . Tucson : University of Arizona. [in English].

12. Methods of Dendrochronology (1990). Applications in the Environmental Sciences / Edward R. Cook and Leonardas A. Kairiukstis (editors). Doredrecht, the Netherlands: Kluwer Academic Publishers and International Institute for Applied Systems Analysis, 394. [in English].

13. Koval Iryna (2013). Climatic signal in earlywood, latewood and total ring width of Crimean pine (Pinus nighra subsp. Pallasiana) from Crimean Mountains, Ukraine . Baltic Forestry. 19(2), 245-251. [in English].

14. Maxime, C. \& Hendrik, D. (2011). 'Effects of climate on diameter growth of cooccurring Fagus sylvatica and Abies alba along an altitudinal gradient' // Trees 25:2, 265-276. [in English].

15. Orwig, D.A. \& Abrams, M.D. (1997). 'Variation in radial growth responses to drought among species, site, and canopy strata'. Trees 11:8, 474-484. [in English].

16. Pilcher, J.R. \& Gray, B. (1982). The relationships between oak tree growth and climate in Britain. Journal of Ecology 70:1, 297-304. [in English]. 